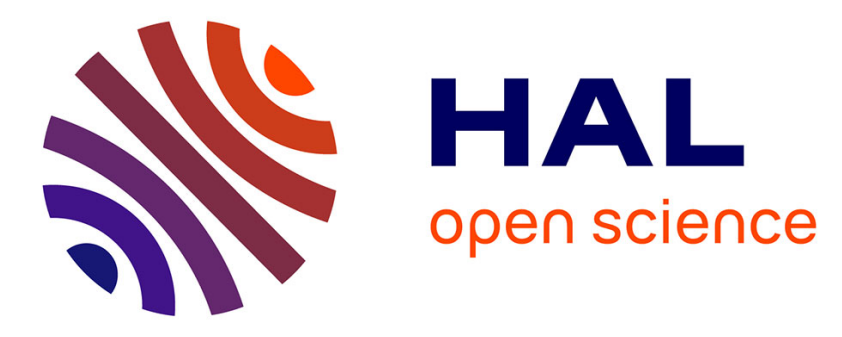

\title{
Preconditioning with Maillard reaction products improves antioxidant defence leading to increased stress tolerance in cardiac cells
}

Stefanie Ruhs, Norbert Nass, Babett Bartling, Hans-Jürgen Brömme, Beatrice Leuner, Veronika Somoza, Ulrich Friess, Rolf-Edgar Silber, Andreas Simm

\section{To cite this version:}

Stefanie Ruhs, Norbert Nass, Babett Bartling, Hans-Jürgen Brömme, Beatrice Leuner, et al.. Preconditioning with Maillard reaction products improves antioxidant defence leading to increased stress tolerance in cardiac cells. Experimental Gerontology, 2010, 45 (10), pp.752. 10.1016/j.exger.2010.08.001 . hal-00625942

\section{HAL Id: hal-00625942 https://hal.science/hal-00625942}

Submitted on 23 Sep 2011

HAL is a multi-disciplinary open access archive for the deposit and dissemination of scientific research documents, whether they are published or not. The documents may come from teaching and research institutions in France or abroad, or from public or private research centers.
L'archive ouverte pluridisciplinaire HAL, est destinée au dépôt et à la diffusion de documents scientifiques de niveau recherche, publiés ou non, émanant des établissements d'enseignement et de recherche français ou étrangers, des laboratoires publics ou privés. 


\section{Accepted Manuscript}

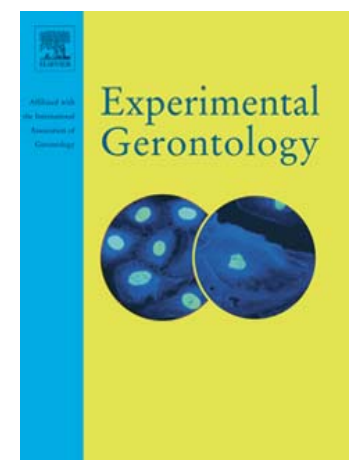

Preconditioning with Maillard reaction products improves antioxidant defence leading to increased stress tolerance in cardiac cells

Stefanie Ruhs, Norbert Nass, Babett Bartling, Hans-Jürgen Brömme, Beatrice Leuner, Veronika Somoza, Ulrich Friess, Rolf-Edgar Silber, Andreas Simm

PII: $\quad$ S0531-5565(10)00225-1

DOI: $\quad$ doi: $10.1016 /$ j.exger.2010.08.001

Reference: $\quad$ EXG 8765

To appear in: $\quad$ Experimental Gerontology

Received date: 26 March 2010

Revised date: $\quad 14$ July 2010

Accepted date: $\quad 3$ August 2010

Please cite this article as: Ruhs, Stefanie, Nass, Norbert, Bartling, Babett, Brömme, Hans-Jürgen, Leuner, Beatrice, Somoza, Veronika, Friess, Ulrich, Silber, Rolf-Edgar, Simm, Andreas, Preconditioning with Maillard reaction products improves antioxidant defence leading to increased stress tolerance in cardiac cells, Experimental Gerontology (2010), doi: 10.1016/j.exger.2010.08.001

This is a PDF file of an unedited manuscript that has been accepted for publication. As a service to our customers we are providing this early version of the manuscript. The manuscript will undergo copyediting, typesetting, and review of the resulting proof before it is published in its final form. Please note that during the production process errors may be discovered which could affect the content, and all legal disclaimers that apply to the journal pertain. 
Preconditioning with Maillard reaction products improves antioxidant defence leading to increased stress tolerance in cardiac cells

Stefanie Ruhs ${ }^{1^{*}}$, Norbert Nass ${ }^{1 \star} \S$, Babett Bartling ${ }^{1}$, Hans-Jürgen Brömme ${ }^{4}$, Beatrice Leuner ${ }^{1}$, Veronika Somoza², Ulrich Friess ${ }^{3}$, Rolf-Edgar Silber ${ }^{1}$, Andreas Simm ${ }^{1}$

Running title: AGE rich food improves cardiac stress tolerance

${ }^{1}$ Department of Cardiothoracic Surgery, Martin-Luther University of Halle-Wittenberg, Halle, Germany

${ }^{2}$ Research Platform for Molecular Food Science, Vienna, Austria

${ }^{3}$ Internal Medicine IV, University of Tuebingen, Tuebingen, Germany

${ }^{4}$ Centre for medical basic research (ZMG), Martin-Luther University of Halle-Wittenberg,

Halle, Germany

* both authors contributed equally to this work

$\$$ corresponding author, current address: Department of Ophthalmology, Martin-Luther

University of Halle-Wittenberg, Halle, Germany

\section{Corresponding author:}

Norbert Nass

Department of Cardiothoracic Surgery

University Halle-Wittenberg

Ernst-Grube-Str. 40

D-06120 Halle

Phone: $\quad+49-345-5577043$

Fax: $\quad+49-345-5577336$

Email: norbert.nass@medizin.uni-halle.de 


\section{Abstract}

Advanced glycation end products (AGEs) are considered as biomarkers of ageing and are associated with several degenerative diseases. Besides endogenous formation, significant amounts of AGEs are taken up with food. Although nutritional AGEs are considered as undesirable, proinflammatory agents, they may also enclose potentially beneficial antioxidants. We used rodent cardiac cells to evaluate if food AGEs, present in bread crust, can modify the cellular antioxidant defence. Mice were fed with bread crust containing diet to prove the in-vivo relevance for the heart. In mouse cardiac fibroblasts, bread crust extract induced a moderate elevation of ROS production causing an activation of $\mathrm{p} 42 / \mathrm{p} 44^{\mathrm{MAPK}}$, p38 ${ }^{\text {MAPK }}$ and NF-KB, followed by increased expression of antioxidative enzymes. Preconditioning studies demonstrated that this was sufficient to protect cardiac fibroblasts and rat adult cardiac myocytes against severe oxidative stress. Furthermore, mice, fed a bread crust containing diet, exhibited a similarly improved cardiac expression of antioxidative defence genes. The consumption of AGEs can therefore contribute to an improved antioxidant status of the heart, thus exhibiting cardioprotective effects in case of severe oxidative stress as in ischemia reperfusion injury. Also, these data show that the exclusive interpretation of circulating AGEs as pathophysiological biomarkers of ageing might be misleading.

\section{Key Words:}

Advanced glycation endproducts, cardiac fibroblasts, cardiomyocytes, oxidative stress, preconditioning 


\section{Introduction}

Advanced glycation end products (AGEs) are formed as stable end products of the Maillard reaction (Ulrich and Cerami 2001) by further oxidations, eliminations and rearrangements. AGEs represent a diverse family of chemical modifications that are found on proteins, lipids and nucleic acids. AGEs are associated with a variety of degenerative diseases like fibrosis, diabetes, nephropathies, retinopathies and Alzheimer's syndrome. Structurally, AGEs are classified as non-fluorescent alkylation products, such as carboxymethyllysine (CML) or carboxyethyllysine (CEL), fluorescent heterocyclic compounds such as arginine-pyrimidine (Arg-Pyr) and cross linking AGEs such as the glyoxal lysine dimer (GOLD) or pentosidine. Some authors also discriminate between toxic (TAGE) and non-toxic AGEs (Takeuchi and Yamagishi 2004; Chuyen 2006).

As AGEs accumulate with age, they are considered as biomarkers for ageing. Age dependent AGE accumulation has for example been shown on human cartilage, skin collagen and pericardial fluid (Dyer et al. 1992; Verzijl et al. 2000; Simm et al. 2007). AGE content in the hippocampus allows the estimation of the age of human cadavers (Sato et al. 2001) and skin collagen glycation and glycoxidation rates are associated with early deaths in C57BL/6NNia mice (Sell et al. 2000).

AGE-modification causes structural alterations on macromolecules, especially proteins. The activity of enzymes can be inhibited by the AGE-modification (Lee et al. 2005), the activity of signalling molecules such as platelet derived growth factor (PDGF) can be disturbed (Nass et al. 2010) as well as the rigidity of the extracellular matrix is strongly enhanced (Bruel and Oxlund 1996). These processes contribute to the physiological decline that is observed in ageing individuals, as it was for example shown that AGE-crosslinks increase cardiac stiffness (Wolffenbuttel et al. 1998; Asif et al. 2000). Besides structural alterations on biomolecules, AGEs interact with several binding proteins or receptors on cells of which the receptor of AGEs (RAGE) has been investigated most extensively (Rong et al. 2005). Activation of RAGE causes stimulation of the proinflammatory NF-KB-pathway (Bierhaus et al. 2005) accompanied by the activation of MAP-kinases like the "stress kinase" p38 MAPK or 
the proliferation associated p42/44 ${ }^{\text {MAPK }}$ (ERK) (Simm et al. 1997; Zill et al. 2003; Ruhs et al. 2007).

AGEs/MRPs can either be generated in situ under physiological conditions using endogenous substrates or taken up from exogenous sources, mainly food. Besides the reducing sugars, a-dicarbonyl compounds like methylglyoxal or glyoxal which arise during glycolysis (Nagaraj et al. 2003; Ghosh et al. 2006), fatty acid degradation and autoxidation of glucose (Fu et al. 1998) can react with free amino acid groups of endogenous proteins and contribute to AGE-formation. Food contains large quantities of Maillard reaction products (MRPs) or AGEs which arise during heating and processing and contribute to the characteristic flavour and colour. Such AGEs can be taken up by humans, have physiological consequences (Koschinsky et al. 1997; Lindenmeier et al. 2002; Vlassara et al. 2002; Somoza 2005; Somoza et al. 2006; Stirban et al. 2006; Goya et al. 2007) and also direct effects on gene expression and oxidative status in organisms. Nevertheless, our knowledge on possible adverse effects especially concerning the heart is far from being comprehensive (Chuyen 2006).

Myocardial infarction is still one of the leading causes of death in the elderly. During myocardial infarction, cardiomyocytes are subjected to nutrient and oxygen deprivation resulting in acidosis. After reperfusion, when oxidative metabolism restarts, huge ion fluxes are observed, concerted with a burst of reactive oxygen species. These events trigger the so called reperfusion injury, which finally results in apoptotic and/or necrotic cell death. Much research has been conducted to identify strategies and substances that can improve the myocardial response to reperfusion injury. So far it is known, that ischemic pre- and postconditioning or the use of antioxidants can have beneficial effects (Brown et al. 2005).

Cardiac tissue contains two major cell types; cardiomyocytes and fibroblasts. Cardiac fibroblasts (CF) are recognized as the major cell type responsible for the homeostatic maintenance of the extracellular matrix (ECM) (Vellaichamy et al. 2005). Cardiac fibroblasts are activated after myocardial infarctions or diseases and contribute to wound healing of the apoptotic or necrotic tissue where a stepwise remodelling of the ECM takes place (Colston et 
al. 2005). Cardiac fibroblasts are also involved in the development of fibrosis (Espira and Czubryt 2009).

Therefore, for this study, a cardiac fibroblast cell line was initially used as a model system to analyze the influence of a model, standardized food-AGE (bread crust extract, BCE) on oxidative stress, signalling events, oxidative and antioxidative enzyme systems and on preconditioning against oxidative stress. In further experiments, cardiomyocytes were used to transfer these results to this entity and additional feeding experiments with mice were conducted to explore the relevance of the results in an animal model. 


\section{Methods}

\subsection{Preparation of bread crust (BC) and bread crust extract (BCE)}

Water-soluble bread crust extract (BCE) was prepared as described previously (Lindenmeier et al. 2002): A mixture of rye flour (108 g, type 1050) water (96 g) and sour dough starter culture (12 g, Boecker, Minden, Germany) was incubated overnight at $26^{\circ} \mathrm{C}$ to obtain a preferment. Sourdough $(1500 \mathrm{~g})$ was prepared by incubating dough of rye flour (type 1150, $674 \mathrm{~g}$ ), preferment $(75 \mathrm{~g})$, and water $(750 \mathrm{~g})$ for $16 \mathrm{~h}$ at $26^{\circ} \mathrm{C}$. Afterwards, rye flour (type 1150, $1117 \mathrm{~g}$ ), wheat flour (type 812, $745 \mathrm{~g}$ ), water (1650 g), sourdough (1241 g), baker's yeast $(43 \mathrm{~g}$ ), and $\mathrm{NaCl}(43 \mathrm{~g})$ were kneaded (dough weight $4839 \mathrm{~g}$ ) to obtain rye/wheat mixed bread dough. This was baked in two baking tins $(5 \mathrm{~cm}$ high), by using the following procedure: dough temperature $\left(28-29^{\circ} \mathrm{C}\right)$, dough rest ing (15 min), dough fermentation (45 $\mathrm{min}$ ), water vaporization (10 s before and $5 \mathrm{~s}$ after the bread was introduced into the oven; after $1 \mathrm{~min}$, the water vapor was removed through the discharge pipe for $1 \mathrm{~min}$ ); baking was performed for $24 \mathrm{~min}$ at $260^{\circ} \mathrm{C}$, followed by $186 \mathrm{~min}$ at $220^{\circ} \mathrm{C}$. Brown bread crust was carefully separated from the bread crumb with a kitchen knife; crust and crumb were frozen in liquid nitrogen and then ground in a mill. Bread crust was stored at $-80^{\circ} \mathrm{C}$ before further use. Bread crust extract (final concentration $250 \mathrm{mg} / \mathrm{mL}$ in Hank's buffered salt solution Invitrogen, Karlsruhe, Germany) was prepared by 15 minutes sonification followed by centrifugation ( $5 \mathrm{~min}, 500 \mathrm{xg}$ ). This solution was stored at $-80^{\circ} \mathrm{C}$ until further use. For some control experiments, BCE was further purified by the Detoxi-Gel Endotoxin Removing Gel (Thermo-Scientific, Bonn, Germany) according to the manufacturer's protocol. Size fractionation was performed by using the YM-10 Microcon centrifugation columns (Millipore, Schwalbach, Germany)

\subsection{Cell culture and treatments}

A cardiac fibroblast cell line (MCF) was established from male C57B/6NCrl mice and cultured as described previously (Ruhs et al. 2007). Adult cardiomyocytes were isolated from 8-10 week-old male Wistar rats of $250-300 \mathrm{~g}$ according to the procedure of Piper (Piper et al. 1982). For the examination of intracellular signalling pathways, fibroblasts were grown to 
confluence, synchronized by cultivation in DMEM $(0.1 \%$ calf serum (CS)) for 48 hours followed by treatment with a water-soluble bread crust extract.

\subsection{Cell proliferation and cycle analysis}

Cells were seeded into 12-well dishes at 5000 cells per $\mathrm{cm}^{2}$ in DMEM containing $5 \% \mathrm{CS}$. After 5 hours, cells were treated with $10 \mathrm{mg} / \mathrm{mL}$ of BCE for indicated time and cells were detached using trypsin to determine the cell number using a Multisizer ${ }^{\mathrm{TM}} 3$ Coulter Counter (Beckman Coulter, Fullerton, CA). For cell cycle analysis, nuclear DNA content was determined by propidium iodide staining and flow cytometry. 500,000 cells were incubated with propidium iodide staining solution $(20 \mu \mathrm{g} / \mathrm{mL}, 100 \mathrm{mM} \mathrm{TRIS} / \mathrm{HCl}, 1.54 \mathrm{mM} \mathrm{NaCl}, 1 \mathrm{mM}$ $\mathrm{CaCl}_{2} 0.5 \mathrm{mM} \mathrm{MgCl}, 0.1 \% \mathrm{NP} 40,0.2 \% \mathrm{BSA}, \mathrm{pH}$ 7.4) for 10 minutes in the dark. The number of proliferating cells (cells in the S and G2 cell cycle phase) was determined using the MultiCycle software (Phoenix Flow Systems; San Diego, CA).

\subsection{Immunoblotting}

Cells were lysed in $50 \mathrm{mmol} / \mathrm{L}$ Tris/ $\mathrm{HCl}, \mathrm{pH}$ 6.7, $2 \%$ SDS, $1 \mathrm{mM} \mathrm{Na}_{3} \mathrm{VO}_{4}, 0.1 \mu \mathrm{M}$ ocadaic acid, 1x complete protease inhibitor (Roche Diagnostics, Mannheim, Germany) for 10 minutes. Organ samples were homogenized in the same buffer and debris removed by centrifugation (5 min, 12,000 $\mathrm{xg}$ ). Denaturated lysates were resolved on SDS-PAGE and transferred onto a nitrocellulose membrane by semidry blotting (Biorad, München, Germany) using blotting buffer (50 mM CAPS, 1mM 3-mercaptopropionic acid, 10\% methanol, pH 10). Detection of specific proteins and phosphorylated kinases was performed using chemiluminescence as described (Ruhs et al. 2007).

\subsection{Intracellular oxidative stress assay}

The formation of reactive oxygen species (ROS) was determined by using $2^{\prime}, 7^{\prime}$ dichlorofluorescin-diacetate $\left(\mathrm{H}_{2}\right.$-DCF-DA; Molecular Probes Europe) as described earlier (Ruhs et al. 2007). Confluent, serum starved cells were washed twice with PBS, detached from the substrate using trypsin and resuspended in Hank's buffered salt solution (HBSS) (Gibco, Karlsruhe, Germany) containing $10 \mathrm{mM}$ glucose. Cells were loaded for 10 minutes with $5 \mu \mathrm{M}$ of the cell-permeant fluorescent dye 2',7'-dichlorodihydrofluorescin diacetate 
$\left(\mathrm{H}_{2}\right.$ DCF-DA). The cells were washed and incubated with $10 \mathrm{mg} / \mathrm{mL} B C E$ or $\mathrm{H}_{2} \mathrm{O}_{2}(25 \mu \mathrm{M})$ in HBSS (Gibco, Karlsruhe, Germany) containing $10 \mathrm{mM}$ glucose for indicated timepoints. To determine the number of dead cells, propidium iodide $(2 \mu \mathrm{g} / \mathrm{mL})$ was added immediately before the analysis. Intracellular oxidised fluorescent $2{ }^{\prime}, 7^{`}$-dichlorofluorescein (DCF) and propidium iodide was determined using an FACSCalibur flow cytometer equipped with CellQuest Pro software (Beckton Dickinson; Heidelberg, Germany). DCF-fluorescence was assessed only in living, PI negative cells.

\subsection{Reporter gene expression studies}

Analysis of the activity of the NF-kB promoter was performed by using the dual luciferase reporter gene system. For transfection, cells were plated at $9 \times 10^{4}$ cells/well in a 96 -well non-crosstalk plate (Greiner, Frickenhausen Germany). pNFkB-TA-Luc (BD Biosciences, California, USA) and phRL-CMV (Promega, Heidelberg, Germany) were cotransfected in a 10:1 ratio using the TransFectin ${ }^{\text {TM }}$ transfection reagent (Bio-Rad Laboratories, Munich Germany) (Ruhs et al. 2007). Luciferase activities was determined according to (Dyer et al. 2000). Firefly activity was expressed normalized to renilla luminescence.

\subsection{RNA extraction and RT-PCR}

Total RNA was prepared using the Qiagen Total RNeasy kit (Hilden, Germany). Reverse transcription of $0.5 \mu \mathrm{g}$ total RNA was performed using the Superscript II reverse transcription system (Invitrogen, Karlsruhe, Germany). The obtained cDNA was diluted twofold with water and used as a template for polymerase chain reaction (PCR). Primer details can be found in table 1.

\subsection{Preconditioning, oxidative stress and simulated ischemia reperfusion}

Serum starved cells (48 hours) were incubated with or without bread crust extract for 24 hours. Afterwards, cells were washed two times with PBS and treated with $0.7 \mathrm{mM} \mathrm{H}_{2} \mathrm{O}_{2}$ for another 24 hours before cell death was determined by PI staining using flow cytometry. In case of inhibitor studies with UO126 $(10 \mu \mathrm{M})$, SB203580 $(5 \mu \mathrm{M})$, N-acetylcysteine $(200 \mu \mathrm{M})$, cells were incubated for $1 \mathrm{~h}$ before bread crust extract was added. 
Cardiomyocytes were plated in M199-medium supplemented with taurine $(5 \mathrm{mM})$, creatine $(5 \mathrm{mM})$ and carnitine $(2 \mathrm{mM})$ (Gibco, Invitrogen, Karlsruhe, Germany), on culture dishes that were preincubated with fetal calf serum (4\%) in M199 medium overnight to facilitate adhesion. After $4 \mathrm{~h}$, medium was replaced, and cells were incubated with or without bread crust extract for $16 \mathrm{~h}$ and then subjected to simulated hypoxia $\left(1 \% \mathrm{O}_{2}\right)$ in Krebs-RingerHEPES buffer (KRH: $115 \mathrm{mM} \mathrm{NaCl}, 5 \mathrm{mM} \mathrm{KCl}, 1 \mathrm{mM} \mathrm{CaCl}_{2}, 1 \mathrm{mM} \mathrm{KH}_{2} \mathrm{PO}_{4}, 1.2 \mathrm{mM} \mathrm{MgSO}$, and 25 mM HEPES buffer ( $\mathrm{pH} 6.2$ for hypoxia or $\mathrm{pH} 7.4$ for reperfusion) for $4 \mathrm{~h}$ in a hypoxy incubator (in vivo 400, hypoxia workstation, Ruskinn, IUL Instruments, Koenigswinter, Germany). After 2-4h simulated reperfusion, cell death was determined as LDH-release by using the "cytotox kit" (Promega, Mannheim, Germany).

\subsection{Determination of free SH-groups by ESR spectroscopy}

Reactive SH-groups (glutathione) were determined in logarithmically growing cells by electron spin resonance spectroscopy (Weiner et al. 1991) using the biradical Bis-(2,2,5,5Tetramethyl-3imidazolin-1-yloxy-4yl)-disulfide as described in (Nass et al. 2009).

Cells were washed with PBS and lysed in Na-phosphate $50 \mathrm{mM} \mathrm{pH} 7.6$ containing Triton X$100(0.1 \%)$ and homogenized using a glass homogenizer. After centrifugation (5 min, 10,000 $\mathrm{x} g$ ), the supernatant was used for protein and $\mathrm{SH}$ determination. Biradical was added $(100 \mu \mathrm{M})$ and three minutes incubated at room temperature and ESR spectrum measured using a Miniscope 100 (Magnettech, Berlin, Germany). SH content was determined by using an external standard (GSH) and normalized for protein content (BCA-test, Pierce, PerBioScience, Bonn, Germany).

\subsection{Animal feeding experiments}

Feeding experiments were performed with three weeks old nude mice (Harlan-Winkelmann Borchen, Germany). Experimental diet consisted of C-1000 control diet (Altromin, Lage, Germany), supplemented with $15 \%(\mathrm{w} / \mathrm{w})$ bread crust or $15 \%(\mathrm{w} / \mathrm{w})$ starch for controls. BC contains approximately $0.55 \mathrm{~g} \mathrm{CML} / \mathrm{kg}$ which calculates to a final content of $0.083 \mathrm{~g} / \mathrm{kg}$ diet. Mice were pair fed with $5 \mathrm{~g}$ of diet per day (corresponds to a CML uptake of $27 \mathrm{mg} \mathrm{CML} / \mathrm{g}$ 
per day). 4 animals per group were fed for 14 days before being sacrificed by cervical dislocation for organ and blood sampling. All animal treatments were approved by the local animal care and use committee.

\subsection{Statistical analysis}

For statistical analysis of data, the two sided unpaired Students's t test or in case of multiple data, one way ANOVA-test was calculated using the SPSS 17.0 software package. For all data standard error (SEM) is given. 


\section{Results}

\subsection{Signal transduction events and gene expression changes triggered by BCE treatment}

In long term treatments of serum starved MCF with BCE, the viability of the cells was not negatively affected (Fig. 1A). Instead, the $30 \mathrm{mg} / \mathrm{mL}$ bread crust extract treatment resulted in enhanced viability. There was also no impairment of cell proliferation over a period of seven days (data not shown). After four days, the BCE treated MCFs showed a significantly increased cell number (Fig. 1B) and this effect was associated with an elevated amount of cells in the S phase of the cell cycle indicating an increased number of proliferating cells (Fig. 1C).

Intracellular signalling pathways were then analysed in more detail. It is well known, that AGE modified proteins can induce cellular radical formation and activation of MAP-kinases and the transcription factor NFKB. Indeed, the treatment of MCFs with $10 \mathrm{mg} / \mathrm{mL}$ BCE for up to 45 minutes resulted in a 1.7 fold significant, but moderate increased ROS production (Fig. 2B). $\mathrm{p} 38^{\mathrm{MAPK}}$ and $\mathrm{p} 42 / 44^{\mathrm{MAPK}}(\mathrm{ERK})$ were also stimulated in a concentration and time dependent manner (Fig. 2A). p38 ${ }^{\mathrm{MAPK}}$ exhibited highest activation after 60 minutes BCE treatment (Fig. $2 \mathrm{~A}$ ) whereas the $\mathrm{p} 42 / 44^{\mathrm{MAPK}}$ was maximally phosphorylated after 5 minutes BCE exposure (Fig. 2A). BCE treatment for two to thirty hours also resulted in an up to fivefold activation of NFKB-luciferase activity in dual luciferase reporter assays comparable to a threefold activation by a $0.2 \mathrm{ng} / \mathrm{mL}$ LPS treatment for 18 hours (Fig 2C). BCE was essentially free of LPS, as removal of LPS by affinity columns did not result in decreased activity (data not shown).

Gene expression was analysed by RT-PCR with special emphasis to genes that are associated with the homeostasis of reactive oxygen species (ROS). As shown in figure 3, expression of xanthine dehydrogenase and the catalytical subunit of the NADP(H) oxidase gp9 $1^{\text {phox }}$ was five- and three-fold higher in cells treated with bread crust extract, whereas nox4, the endothelial NADPH-oxidase, cox7c, a small regulatory subunit of the mitochondrial cytochrome-C-oxidase, and also lipoxygenases were not significantly regulated in response 
to bread crust extract treatment (data not shown). Despite this increased expression of genes with prooxidative properties, the expression of the stress induced protein (SIP), which is activated in response to various noxes such as ROS (Tomasini et al. 2001; Tomasini et al. 2002) remained unaltered (Fig. 3).

Vanin-1 and -3 , were increased 5 and 10-fold, respectively (Fig. 3). Vanins are pantetheinases which permit the recycling of pantotheine to pantethonate and hereby generate cysteamine, a strong antioxidant (Pitari et al. 2000). Peroxiredoxines, which also function as radical scavengers, were only slightly, but nevertheless significantly elevated (data not shown).

Within the family of superoxidedismutases (SOD), the mitochondrial Mn-SOD was strongly upregulated (12-fold), the extracellular SOD exhibited a less pronounced mRNA accumulation (2.5-fold), whereas the cytosolic Cu/Zn-SOD remained unchanged (Fig. 3).

Metallothioneins 1,-2, (Mt1, Mt2) which are cytosolic heavy metal binding proteins were upregulated up to 6-fold in case of methallothionine-2. Methallothionines have been implicated in cardioprotection against oxidative damage by releasing zinc and forming disulfides (Feng et al. 2006). Ceruloplasmin (Cp) which is involved in metal homeostasis of copper and iron, was upregulated 4-fold (Fig. 3). Copper and iron are involved in many aspects of oxidative stress and ceruloplasmin knock-out mice showed increased susceptibility to oxidative stress (Patel et al. 2002) in the central nervous system. We also determined the amount of free $\mathrm{SH}$-groups, as estimation for reduced glutathione. Free $\mathrm{SH}$ groups were increased significantly from $29.7 \pm 1.9$ to $36.7 \pm 1.8 \mu \mathrm{mol} / \mathrm{g}$ protein after BCE treatment. Taken together, the upregulation of a subset of ROS-generating enzymes was well balanced by an elevated expression of antioxidative enzymes and proteins (Fig. 3). The SOD family members were further analysed on the protein level by immunoblotting. In both cases, RT-PCR data and western blot data correlated well with each other (Fig. 4). 


\subsection{Preconditioning of MCFs and rat cardiomyocytes with bread crust extract against oxidative stress and simulated ischemia/reperfusion}

From the expression pattern identified, we speculated that bread crust extract pre-treatment might be protective against further oxidative stress. As a model for oxidative stress, cells were treated with $\mathrm{H}_{2} \mathrm{O}_{2}$ for 24 hours at a concentration which killed approximately $50-80 \%$ of the cells. After preconditioning with $\mathrm{BCE}$, cell death rate in response to hydrogenperoxide was reduced to at least $50 \%$. Due to the washing steps a direct anti-oxidative effect of extracellular BCE could be excluded. For adult cardiomyocytes, the effect of bread crust preincubation on simulated ischemia reperfusion injury was also investigated. Cardiomyocytes were preincubated with bread crust and then subjected to simulated ischemia, characterized by no glucose, acidic $\mathrm{pH}$ and $1 \% \mathrm{O}_{2}$ and then reoxygenated in the presence at $\mathrm{pH} 7.4$ (reperfusion). Again, a protective effect of bread crust extract preconditioning was observed (Fig. 6).

To elucidate which signal transduction element was essential for changes in gene expression and responsible for the protection against ischemia reperfusion injury, the effects of the antioxidant N-acetylcysteine (NAC) and the MAP-kinase inhibitors U0126 (ERK-inhibitor) and SB203580 (upstream inhibitor of p38 ${ }^{\mathrm{MAPK}}$ ) were analyzed.

The antioxidant $\mathrm{N}$-acetylcysteine (NAC) had significant effects on the BCE-induced RNA accumulation for Mt2, gp91 ${ }^{\text {phox }}$, Vnn1, Vnn3 but no effect on MnSOD, SOD3, Cp, and XDH (Tab. 1). UO126 inhibited the phosphorylation of ERK and SB203580 the phosphorylation of MAPKAP2 efficiently under the conditions used (data not shown). The ERK inhibitor caused a significant decrease in activation of $\mathrm{Cp}$, Mt2, MnSOD and $\mathrm{Vnn3}$, whereas the decrease in gp9 $1^{\text {phox }}$ RNA-accumulation was not significant. SOD3 and Vnn1 RNA-accumulation was unchanged and XDH-RNA was elevated by U0126 alone (Tab. 1). For SB203580 a significant decrease in RNA accumulation after BCE-treatment was observed for Vnn3; the decreases for Vnn1 and MnSOD were insignificant and Mt2, Cp, gp91 ${ }^{\text {phox }}$ and SOD3 RNA accumulation was unaffected. XDH-RNA accumulation was again elevated by addition of the inhibitor without BCE-treatment (Tab. 2). 
In terms of preconditioning, NAC and UO126 significantly decreased the pre-treatment effect, but were unable to abolish it completely. In contrast SB203580 had no significant effect on preconditioning (Fig. 5).

\subsection{BC feeding experiments}

To further analyze if bioactive components from bread crust extract orally administered can cause effects on the heart of organisms, we conducted a feeding experiment with nude (nu/nu) mice. Mice were fed for 2 weeks with a diet poor in AGEs and the same diet supplemented with bread crust extract. To analyze if AGEs were absorbed, we determined the fluorescence as a marker for fluorescent AGEs which are present in high amounts in bread crust, as well as the protein bound carboxymethyllysine (CML) in serum samples. Both parameters were increased in bread crust fed animals by about $20 \%$ (Fig. 7), but only changes in fluorescence were significant $(p<0.05)$. The expression of major bread crust responsive genes in cell culture was analysed in the hearts of the mice and a significant increase for MnSOD, EcSOD, ceruloplasmin and gp91 ${ }^{\text {phox }}$ was observed (Fig. 7).

\section{Discussion}

During aging and diseases such as diabetes and end stage-renal disease, increasing amounts of AGE-modified proteins, especially in the extracellular matrix have been detected and are involved in the development of several degenerative diseases (For review see: Nass et al., 2007). In relation to cardiac diseases for example, Meerwaldt et al. (2007) could show in a 5 year follow up study with diabetic patients that AGE-associated skin autofluorescence was strongly associated with cardiac mortality. In an animal model (C57BL/6NNia mice), markers of skin collagen glycation and glycoxidation rates could predict early deaths (Sell et al. 2000). Endogenous AGEs resulting from a high fat diet have also been linked to cardiac inflammation and fibrosis (Tikellis et al 2008).

Nevertheless, it has been controversially discussed, if food-AGEs/MRPs (Webster et al. 2005) may have pathophysiological impacts on healthy organisms, comparable to in situ and 
in vivo generated AGEs (Somoza 2006; Sebekova and Somoza 2007; Somoza 2008). There is now compiling evidence that food-derived AGEs are absorbed, transported into circulation and excreted with the urine. This has, for example, been demonstrated for free- and caseinlinked $N(\varepsilon)$-fructoselysine and $N(\varepsilon)$-carboxymethyllysine (Bergmann et al. 2001; Somoza et al. 2006) but the uptake rate strongly depended on the compound analysed. Indirect evidence for the uptake of nutritional AGEs has also been obtained from animal studies and also human trials that demonstrated physiological consequences of nutritional AGEs in peripheral tissues/organs (Koschinsky et al. 1997; Somoza et al. 2005; Chuyen 2006; Stirban et al. 2006). Also, for long term feeding with an AGE-rich diet, a shortening of life span in mice was observed (Cai et al. 2007). On the other hand, experimental data regarding the heart are largely missing.

At old age, the cardiovascular diseases such as myocardial infarction are the major cause of death. In this context, reperfusion injury is believed to be one major cause of cell death after myocardial infarction. A reperfusion associated burst of reactive oxygen is proposed to be a major trigger of necrotic and apoptotic cell death. Approaches to improve the survival of cardiomyocytes in this process have great potential to reduce the incidence of cardiac death (Pell et al. 1997; Valen 2003; Murphy and Steenbergen 2008; Hausenloy and Yellon 2009). One strategy to improve resistance of cells to reperfusion injury is ischemic preconditioning (IP), where a short phase of ischemia prepares the cells for prolonged periods of ischemia followed by reperfusion. Unfortunately, IP is not efficient in tissue from old humans (Juhaszova et al., 2005; Bartling et al., 2003).

In this study, we used bread crust extract (BCE) produced under standardized conditions as MRP/AGE containing model food extract (Lindenmeier et al. 2004, Sebekova et al. 2005, Somoza et al. 2005). In a previous study (Ruhs et al. 2007) we have shown with specific antibodies that BCE contained a variety of AGEs, namely Arg-pyridine, GA-pyridine, pentosidine, 3-deoxyglucusone-imidazolone, CML and also uncharacterized AGEs that cross reacted with an antiserum raised against glucose modified BSA. Treatment with this food extract led to an increased antioxidant defence in a cardiac fibroblast cell line and similar 
effects were observed in cardiac tissue of mice in feeding experiments. As a result, cardiac fibroblasts and also adult cardiomyocytes from rats were protected against exogenous oxidative stress. We therefore propose that an alimentary intervention with AGEs - primarily thought to be always harmful for tissue function - might be beneficial in the case of myocardial ischemia reperfusion.

As a prerequisite for achieving effects in a peripheral organ such as the heart, bioactive substances must be taken up into the blood stream to reach the target tissue. The elevated AGE-related fluorescence in serum of BC-fed mice, and the observed gene expression changes in cardiac tissue clearly demonstrated that bioactive BCE components could reach the cardiac tissue. In cell models for cardiac diseases we observed no toxic effects of the BCE treatment (Fig. 2A). We have also shown previously (Ruhs et al. 2007) that BCE did not cause cardiac fibroblasts to switch to the myofibroblast phenotype, but rather decreases the expression of genes associated with fibrosis.

A moderate rise in ROS as observed after stimulation of cardiac fibroblasts with BCE can be sufficient to trigger the detected activation of the mitogen-activated protein kinases (MAPK) such as $\mathrm{p} 42 / \mathrm{p} 44^{\mathrm{MAPK}}$ and $\mathrm{p} 38^{\mathrm{MAPK}}$ as well the activation of the transcription factor NFKB (Martindale and Holbrook 2002; Winyard et al. 2005). Although we did not show the source of reactive oxygen, we think, based on other studies and the increase in expression of NADPH-oxidase subunits that such enzymes were responsible for the generation of ROS in response to $B C E$ treatment. We demonstrated a significant contribution of ROS to the signalling process by pretreatment with the antioxidant NAC which decreased the effects of BCE on gene expression (Tab. 1) and accordingly, also the BCE preconditioning effect. The MAP-kinase inhibitors UO126 and SB203580 had smaller effects on preconditioning and also fewer genes were influenced. As a result of these signals, the expression of oxidative and antioxidative enzyme systems was altered. This resulted in protection against severe oxidative stress in the MCFs as well as in cardiomyocytes. Deduced from the gene expression pattern, SODs, ceruloplasmin, and vanins seem to be responsible for the 
increased tolerance towards oxidative stress. The increased amount of the antioxidant GSH (SH-groups) could further contribute to the improved antioxidant defence.

The mechanism by which the cells detect the BCE compounds was not analysed in this study. Nevertheless, it has been described that RAGE contributes to the perception of endogenous AGEs as well as for BCE (Vlassara 2001; Zill et al. 2001; Zill et al. 2003). Interestingly it has been shown (Shang et al. 2010) that the RAGE-ligand interaction is also crucial for the gene regulation in hypoxia reoxygenation injury in cardiomyocytes from mice. Both, RAGE and RAGE-ligands are elevated after simulated ischemia/reperfusion and AKT is a key player in this reaction, similar to the situation in ischemic preconditioning (IP). In the absence of RAGE, cardiomyocytes are more resistant to reoxygenation injury, which is in accordance to another study (Andrassy et al. 2008) that demonstrated significantly reduced damage in reperfused hearts of RAGE -/- mice if compared to wild type. In contrast to these studies, we have employed a putative RAGE-AGE interaction prior to simulated ischemiareperfusion. Although we have not yet analysed if the preconditioning effect has an impact on the ischemia-reoxygenation reponse itself, we have no indication that the AGE-pretreatment alters the expression of RAGE in the cells. We therefore propose that the observed preconditioning effect relied mostly on improved antioxidant defence and did not influence the RAGE-AGE interaction during hypoxia / reoxygenation.

In comparison to the effects of ischemic preconditioning (IP), which also results in improved antioxidants defence, BCE treatment did not result in increased AKT-phosphorylation (reviewed in: (Murphy and Steenbergen 2008) but induced an early decrease in AKT phosphorylation which returned to normal levels already within $1 \mathrm{~h}$ of treatment. Nevertheless, the involvement of reactive oxygen species and also ERK suggests that the activation of antioxidative defence by BCE relies on partially overlapping mechanisms as the response to ischemic preconditioning.

It is documented that the antioxidative capacity of the heart, despite its high metabolic demand and high mitochondrial activity is weak in comparison to the liver but adequate under normal physiological conditions. However, it appears that the heart and the including 
cells are not particularly well equipped to deal with strong elevated ROS concentrations generated by an oxidative burst such as in ischemia-reperfusion stress (Kang 1999). Nutritional preconditioning might therefore be an interesting possibility to improve the resistance of cardiac cells to noxes such as reactive oxygen species produced under reperfusion conditions. However, it is not clear from our studies if long term AGE-rich nutrition might also be beneficial. Chronic feeding with an AGE reduced diet seemed to extend the life span of mice (Cai et al. 2007), but as MRPs/AGEs represent a diverse family of chemical compounds the source, structure and composition of AGEs from food might be very important. It will therefore be crucial for further studies to identify the compound in BCE which was responsible for the protective effect. Initial experiments using CML-modified proteins and pronyl-lysine failed in reproducing the BCE preconditioning effect (S. Ruhs, unpublished results). Nevertheless, we suggest that the model of AGEs being always harmful by for example accelerating the ageing process has to be reassessed. 


\section{Acknowledgements}

This work was supported by a grant of the Deutsche Forschungsgemeinschaft to A.S. (Si$1317 / 1-1)$, and by the Wilhelm-Roux-Program of the Medical Faculty Halle, which is funded by the German Bundesministerium fuer Bildung und Forschung (BMBF; NBL 3, FKZ14/45, 13/01). B.L. received a fellowship of the "Freunde und Foerderer der Martin-Luther Universitaet Halle-Wittenberg" 


\section{Legends to the Figures}

Fig. 1: Influence of bread crust extract on cell viability, cell cycle and proliferation. BCE did not induce cell death but instead enhanced the viability at a concentration of 30 $\mathrm{mg} / \mathrm{mL}$. Confluent serum starved cells were incubated with different concentrations of BCE for 24 hours. Cell death was determined using propidium iodine (PI) staining (A). Treatment with BCE resulted in an increasing amount of cells in S-Phase of the cell cycle (C) and elevated cell number (B). Sub-confluent cells were incubated with bread crust for four days and the cell cycle phases were determined using PI staining and the cell numbers were determined using a Coulter counter. Values are given as mean \pm S.E.M. $(n=3)$ of three independent experiments with ${ }^{*} p<0.01$ and ${ }^{* *} p<0.001$ versus untreated control.

Fig. 2: Influence of bread crust extract on cell signalling. A: Time and dose dependent effects of BCE on MAP-kinase signalling. In the upper panel representative Western Blots are shown. B: Production of reactive oxygen species as determined by the DCFDA assay as described in the materials and methods section. C: Activation of an NF-kB-luciferase reporter construct by BCE treatment and LPS as positive control. Data represent means of three independent experiments $+/-$ SEM. ${ }^{*}: p<0.05 ;{ }^{* *}: p<0.01$.

Fig. 3: Influence of bread crust extract on the expression of oxidative and antioxidative enzyme systems

Treatment of MCF with BCE leads to a moderate elevation of oxidative enzyme systems whereas antioxidative enzymes like Mn-SOD, Mt-2 and $\mathrm{Cp}$ are strongly activated. Confluent, serum starved cells were incubated with $10 \mathrm{mg} / \mathrm{ml}$ BCE for 24 hours following by RNA isolation and RT-PCR as described in materials and methods. A: representative PCR experiments are shown; B-E: Quantification of PCR-results. Data were normalized towards 18S-RNA. Untreated controls were set to $100 \%$. 
Fig. 4: Influence of bread crust extract on the protein expression of the SOD enzymes Incubation of MCF with BCE leads to an increased of Mn-SOD and Ec-SOD protein expression whereas $\mathrm{Cu}-\mathrm{Zn}-\mathrm{SOD}$ expression was not altered. Confluent serum starved cells were incubated for 24 hours with $10 \mathrm{mg} / \mathrm{ml} \mathrm{BCE}$ and detection of the SOD enzymes was performed as described in materials and methods. Values are given as mean \pm S.E.M. $(n=$ 4) of three independent experiments with ${ }^{*} P<0.05$ and ${ }^{* *} P<0.01$ versus untreated control.

Fig. 5: Protection of MCF against oxidative stress by preconditioning using BCE Preconditioning of MCF with BCE for 16 hours protects these cells against oxidative stress induced cell death. Confluent serum starved cells were incubated for 24 hours with $10 \mathrm{mg} / \mathrm{mL}$ bread crust extract (BCE), washed two times to remove BCE quantitatively and incubated of another 24 hours with $0.7 \mathrm{mM} \mathrm{H}_{2} \mathrm{O}_{2}$. The amount of cell death was determined using $\mathrm{PI}$ staining. Values are given as mean \pm S.E.M. $(n=4)$ of four independent experiments with * $p$ $<0.05$ and ${ }^{* *} p<0.01$ versus untreated control. Cells were preincubated with inhibitors for $1 \mathrm{~h}$ before BCE or only solvent was added for another $16 \mathrm{~h}$. Hydrogenperoxide was then added after washing the cells 2 -times to remove BCE and inhibitors for further $24 \mathrm{~h}$ before cell death was determined by propidium iodide and flow cytometry. Experiments were repeated at least three times. Because hydrogen peroxide induced cell death varied significantly for individual experiments, only one representative result is shown.

Fig. 6: Adult rat cardiomyocytes can be protected against simulated ischemia reperfusion injury by BCE preconditioning. Cardiomyocytes were preincubated with BCE $(10 \mathrm{mg} / \mathrm{mL})$ for $16 \mathrm{~h}$ before simulated ischemia/reperfusion. Cell death was determined by using LDH release. Data represent average of 3 individual experiments with 4 replicas each. Standard error is given and data are significant with $p<0.01$ (Student's T-test). 
Fig. 7: Mice were fed with bread crust and changes in serum AGE-content in serum and gene- and protein expression in cardiac tissue were determined. Serum fluorescence was determined with excitation at $360 \mathrm{~nm}$ and emission at $440 \mathrm{~nm}$. Protein-bound CML was determined by using a CML antiserum in dot blot experiments as described in the material and methods section. A and B: AGE related fluorescence and CML in serum. C and D show mRNA- and protein accumulation in cardiac tissue samples. 


\section{References}

Andrassy, M., Volz, H.C., Igwe, J.C., Funke, B., Eichberger, S.N., Kaya, Z., Buss, S., Autschbach, F., Pleger, S.T., Lukic, I.K., Bea, F., Hardt, S.E., Humpert, P.M., Bianchi, M.E., Mairbäurl, H., Nawroth, P.P., Remppis, A., Katus, H.A., Bierhaus, A. 2008. Highmobility group box-1 in ischemia-reperfusion injury of the heart. Circulation. Jun 24;117(25):3216-26.

Asif, M., Egan, J., Vasan, S., Jyothirmayi, G. N., Masurekar, M. R., Lopez, S., Williams, C., Torres, R. L., Wagle, D., Ulrich, P., Cerami, A., Brines M., Regan, T. J. 2000. An advanced glycation endproduct cross-link breaker can reverse age-related increases in myocardial stiffness. Proc. Natl. Acad. Sci. U. S. A. 97(6) 2809-2813

Bartling, B., Friedrich, I., Silber, R.E., Simm, A. 2003. Ischemic preconditioning is not cardioprotective in senescent human myocardium. Ann. Thorac. Surg. 2003 76(1) 105111.

Bergmann, R., Helling, R., Heichert, C., Scheunemann, M., Mading, P., Wittrisch, H., Johannsen, B., Henle, T., 2001. Radio fluorination and positron emission tomography (PET) as a new approach to study the in vivo distribution and elimination of the advanced glycation endproducts $\mathrm{N}$ epsilon-carboxymethyllysine (CML) and $\mathrm{N}$ epsiloncarboxyethyllysine (CEL). Nahrung 45(3) 182-188.

Bierhaus, A., Humpert, P. M., Morcos, M., Wendt, T., Chavakis, T., Arnold, B., Stern, D. M., Nawroth P., 2005. Understanding RAGE, the receptor for advanced glycation end products. J. Mol. Med. 83(11) 876-886.

Brown, R. D., Ambler, S. K., Mitchell, M. D., Long C. S., 2005. The cardiac fibroblast therapeutic target in myocardial remodeling and failure. Annu. Rev. Pharmacol. Toxicol. $45657-687$

Bruel, A., Oxlund H., 1996. Changes in biomechanical properties, composition of collagen and elastin, and advanced glycation endproducts of the rat aorta in relation to age. Atherosclerosis 127(2) 155-165. 
Bucciarelli, L.G., Ananthakrishnan, R., Hwang, Y.C., Kaneko, M., Song, F., Sell, D.R., Strauch, C., Monnier, V.M., Yan, S.F., Schmidt, A.M., Ramasamy, R. 2008. RAGE and modulation of ischemic injury in the diabetic myocardium. Diabetes. 57(7):1941-51.

Cai, W., He, J. C., Zhu, L., Chen, X., Wallenstein, S., Striker, G. E., Vlassara, H., 2007. Reduced oxidant stress and extended lifespan in mice exposed to a low glycotoxin diet association with increased AGER1 expression. Am. J. Pathol. 170(6) 1893-1902.

Chuyen, N. V., 2006. Toxicity of the AGEs generated from the Maillard reaction on the relationship of food-AGEs and biological-AGEs. Mol. Nutr. Food Res. 50(12) 11401149

Colston, J. T., de la Rosa, S. D., Strader, J. R., Anderson, M. A., Freeman G. L., 2005. $\mathrm{H}_{2} \mathrm{O}_{2}$ activates Nox4 through $\mathrm{PLA}_{2}$-dependent arachidonic acid production in adult cardiac fibroblasts. FEBS Lett. 579(11) 2533-2540.

Dyer, B. W., Ferrer, F. A., Klinedinst, D. K., Rodriguez, R., 2000. A noncommercial dual luciferase enzyme assay system for reporter gene analysis. Anal. Biochem. 282(1) 158-161.

Dyer, D. G., Dunn, J. A., Thorpe, S. R., Lyons, T. J., McCance, D. R., Baynes J. W., 1992. Accumulation of Maillard reaction products in skin collagen in diabetes and aging. Ann. N. Y. Acad. Sci. 663 421-422.

Espira, L., Czubryt, M. P., Emerging concepts in cardiac matrix biology, Can. J. Physiol. Pharmacol. 2009 87(12) 996-1008.

Feng, W., Benz, F. W., Cai, J., Pierce, W. M., Kang, Y. J., 2006. Metallothionein disulfides are present in metallothionein-overexpressing transgenic mouse heart and increase under conditions of oxidative stress. J. Biol. Chem. 281(2) 681-687.

Fu, S., Fu, M. X., Baynes, J. W., Thorpe, S. R., Dean, R. T., 1998. Presence of dopa and amino acid hydroperoxides in proteins modified with advanced glycation end products (AGEs) amino acid oxidation products as a possible source of oxidative stress induced by AGE proteins. Biochem. J. 330 ( Pt 1) 233-239. 
Ghosh, M., Talukdar, D., Ghosh, S., Bhattacharyya, N., Ray, M., Ray S., 2006. In vivo assessment of toxicity and pharmacokinetics of methylglyoxal. Augmentation of the curative effect of methylglyoxal on cancer-bearing mice by ascorbic acid and creatine. Toxicol. Appl. Pharmacol. 212(1) 45-58.

Goya, L., Delgado-Andrade, C., Rufian-Henares, J. A., Bravo, L., Morales, F. J., 2007. Effect of coffee melanoidin on human hepatoma HepG2 cells. Protection against oxidative stress induced by tert-butylhydroperoxide. Mol. Nutr. Food. Res. 51(5) 536-45.

Hausenloy, D. J., Yellon, D. M., 2009. Preconditioning and postconditioning underlying mechanisms and clinical application. Atherosclerosis 204(2) 334-341.

Juhaszova, M., Rabuel, C., Zorov, D.B., Lakatta, E.G., Sollott, S.J. 2005. Protection in the aged heart: preventing the heart-break of old age? Cardiovasc. Res. 66(2):233-244

Kang, Y. J. 1999. The antioxidant function of metallothionein in the heart. Proc. Soc. Exp. Biol. Med. 222(3) 263-273.

Koschinsky, T., He, C. J., Mitsuhashi, T., Bucala, R., Liu, C., Buenting, C., Heitmann, K., Vlassara, H., 1997. Orally absorbed reactive glycation products (glycotoxins) an environmental risk factor in diabetic nephropathy. Proc. Natl. Acad. Sci. U. S. A. 94(12) 6474-6479

Lee, H. J., Howell, S. K., Sanford, R. J., Beisswenger, P. J., 2005. Methylglyoxal can modify GAPDH activity and structure. Ann. N. Y. Acad. Sci. 1043 135-145.

Lindenmeier, M., Faist, V., Hofmann, T., 2002. Structural and functional characterization of pronyl-lysine, a novel protein modification in bread crust melanoidins showing in vitro antioxidative and phase I/II enzyme modulating activity. J. Agric. Food Chem. 50(24) $6997-7006$

Lindenmeier, M., Hofmann, T. 2004. Influence of Baking Conditions and Precursor Supplementation on the Amounts of the Antioxidant Pronyl-L-lysine in Bakery Products J. Agric. Food Chem., 52, 350-354

Martindale, J. L., Holbrook, N. J., 2002. Cellular response to oxidative stress signaling for suicide and survival. J. Cell Physiol. 192(1) 1-15. 
Meerwaldt, R., Lutgers, H.L., Links, T.P., Graaff, R., Baynes, J.W., Gans, R.O., Smit, A.J., 2007 Skin autofluorescence is a strong predictor of cardiac mortality in diabetes. Diabetes Care. 30(1) 107-112.

Murphy, E., Steenbergen, C., 2008. Mechanisms underlying acute protection from cardiac ischemia-reperfusion injury. Physiol. Rev. 88(2) 581-609.

Nagaraj, R. H., Oya-Ito, T., Padayatti, P. S., Kumar, R., Mehta, S., West, K., Levison, B., Sun, J., Crabb, J. W., Padival, A. K., 2003. Enhancement of chaperone function of alpha-crystallin by methylglyoxal modification. Biochemistry $42(36)$ 10746-10755.

Nass, N., Bartling, B., Navarrete Santos, A., Scheubel, R.J., Börgermann, J., Silber, R.E., Simm, A. 2007. Advanced glycation end products, diabetes and ageing. Z. Gerontol. Geriatr. 40(5), 349-356.

Nass, N., Kukat, A., Seibel, P., Bromme, H. J., Schinzel, R., Silber, R. E., Simm, A., 2009. Advanced glycation endproduct accumulation in rho ${ }^{(0)}$ cells without a functional respiratory chain. Biol. Chem. 390(9) 915-919.

Nass, N., Vogel, K., Hofmann, B., Presek, P., Silber, R. E., Simm, A., 2010. Glycation of PDGF results in decreased biological activity. Int. J. Biochem. Cell Biol. 42(5):749754.

Patel, B. N., Dunn, R. J., Jeong, S. Y., Zhu, Q., Julien, J. P., David, S., 2002. Ceruloplasmin regulates iron levels in the CNS and prevents free radical injury. J. Neurosci. 22(15) 6578-9586.

Pell, T. J., Yellon, D. M., Goodwin, R. W., Baxter, G. F., 1997. Myocardial ischemic tolerance following heat stress is abolished by ATP-sensitive potassium channel blockade. Cardiovasc. Drugs Ther. 11(5) 679-686.

Piper, H. M., Probst, I., Schwartz, P., Hutter, F. J., Spieckermann, P. G., 1982. Culturing of calcium stable adult cardiac myocytes. J. Mol. Cell. Cardiol. 14(7) 397-412.

Pitari, G., Malergue, F., Martin, F., Philippe, J. M., Massucci, M. T., Chabret, C., Maras, B., Dupre, S., Naquet, P., Galland, F., 2000. Pantetheinase activity of membrane-bound 
Vanin-1 lack of free cysteamine in tissues of Vanin-1 deficient mice. FEBS Lett. 483(23) $149-154$.

Rong, L. L., Gooch, C., Szabolcs, M., Herold, K. C., Lalla, E., Hays, A. P., Yan, S. F., Yan, S. S., Schmidt, A. M., 2005. RAGE a journey from the complications of diabetes to disorders of the nervous system - striking a fine balance between injury and repair. Restor. Neurol. Neurosci. 23(5-6) 355-365.

Rueckschloss, U., Quinn, M. T., Holtz, J., Morawietz, H., 2002. Dose-dependent regulation of $\mathrm{NAD}(\mathrm{P}) \mathrm{H}$ oxidase expression by angiotensin II in human endothelial cells protective effect of angiotensin II type 1 receptor blockade in patients with coronary artery disease. Arterioscler. Thromb. Vasc. Biol. 22(11) 1845-1851.

Ruhs, S., Nass, N., Somoza, V., Friess, U., Schinzel, R., Silber, R. E., Simm, A., 2007. Maillard reaction products enriched food extract reduce the expression of myofibroblast phenotype markers. Mol. Nutr. Food Res. 51(4) 488-495.

Sato, Y., Kondo, T., Ohshima, T., 2001. Estimation of age of human cadavers by immunohistochemical assessment of advanced glycation end products in the hippocampus. Histopathology 38(3) 217-220.

Šebeková, K., Hofmann, T., Boor, P., Šebeková, K., Uličná, O., Erbersdobler, H.F., Baynes, J.W., Thorpe, S.R., Heidland, A., Somoza, V. 2005 Renal effects of oral Maillard reaction products load in form of bread crusts in healthy and subtotally nephrectomized rats. Ann. N.Y. Acad. Sci. 1043 482-491

Sebekova, K., Somoza, V., 2007. Dietary advanced glycation endproducts (AGEs) and their health effects--PRO. Mol. Nutr. Food Res. 51(9) 1079-1084.

Sell, D. R., Kleinman, N. R., Monnier, V. M., 2000. Longitudinal determination of skin collagen glycation and glycoxidation rates predicts early death in C57BL/6NNIA mice. Faseb J. 14(1) 145-156.

Shang, L., Ananthakrishnan, R., Li, Q., Quadri, N., Abdillahi, M., Zhu, Z., Qu, W., Rosario, R., Touré, F., Yan, S.F., Schmidt, A.M., Ramasamy, R. 2010. RAGE modulates 
hypoxia/reoxygenation injury in adult murine cardiomyocytes via JNK and GSK-3beta signaling pathways. PLoS One. 5(4): e10092.

Simm, A., Munch, G., Seif, F., Schenk, O., Heidland, A., Richter, H., Vamvakas, S., Schinzel, R., 1997. Advanced glycation endproducts stimulate the MAP-kinase pathway in tubulus cell line LLC-PK1. FEBS Lett. 410(2-3) 481-484.

Simm, A., Wagner, J., Gursinsky, T., Nass, N., Friedrich, I., Schinzel, R., Czeslik, E., Silber, R. E., Scheubel, R. J., 2007. Advanced glycation endproducts a biomarker for age as an outcome predictor after cardiac surgery? Exp. Gerontol. 42(7) 668-675.

Somoza, V., Lindenmeier, M., Hofmann, T., Frank, O., Erbersdobler, H.F., Baynes, J.W., Thorpe, S.R., Heidland, A., Zill, H., Bek, S., Huber, J., Weigle, T., Scheidler, S., Busch, A.E., Sebekova, K. 2005. Dietary bread crust advanced glycation end products bind to the receptor for AGEs in HEK-293 kidney cells but are rapidly excreted after oral administration to healthy and subtotally nephrectomized rats. Ann. N.Y. Acad. Sci. 1043 492-500

Somoza, V., 2005. Five years of research on health risks and benefits of Maillard reaction products an update. Mol. Nutr. Food Res. 49(7) 663-672.

Somoza, V., 2006. Health implications of thermally processed foods -COST Action 927. Mol. Nutr. Food Res. 50(9) 787-788.

Somoza, V., Wenzel, E., Lindenmeier, M., Grothe, D., Erbersdobler, H. F., Hofmann, T., 2005. Influence of feeding malt, bread crust, and a pronylated protein on the activity of chemopreventive enzymes and antioxidative defense parameters in vivo. J. Agric. Food Chem. 53(21) 8176-8182.

Somoza, V., Wenzel, E., Weiss, C., Clawin-Radecker, I., Grubel, N., Erbersdobler, H. F., 2006. Dose-dependent utilisation of casein-linked lysinoalanine, N(epsilon)fructoselysine and N(epsilon)-carboxymethyllysine in rats. Mol. Nutr. Food Res. 50(9) 833-841.

Somoza, V., 2008. Physiological effects of thermally treated foods. Mol. Nutr. Food Res. 52(3) 305-306. 
Tikellis, C., Thomas, M.C., Harcourt, B.E., Coughlan, M.T., Pete, J., Bialkowski, K., Tan, A., Bierhaus, A., Cooper, M.E., Forbes, J.M. 2008. Cardiac inflammation associated with a Western diet is mediated via activation of RAGE by AGEs. Am. J. Physiol. Endocrinol. Metab. 295: E323-E330.

Stirban, A., Negrean, M., Stratmann, B., Gawlowski, T., Horstmann, T., Gotting, C., Kleesiek, K., Mueller-Roesel, M., Koschinsky, T., Uribarri, J., Vlassara, H., Tschoepe D., 2006. Benfotiamine prevents macro- and microvascular endothelial dysfunction and oxidative stress following a meal rich in advanced glycation end products in individuals with type 2 diabetes. Diabetes Care 29(9) 2064-2071.

Takeuchi, M., Yamagishi, S., 2004. TAGE (toxic AGEs) hypothesis in various chronic diseases. Med. Hypotheses 63(3) 449-452.

Tomasini, R., Samir, A. A., Vaccaro, M. I., Pebusque, M. J., Dagorn, J. C., Iovanna, J. L., Dusetti, N. J., 2001. Molecular and functional characterization of the stress-induced protein (SIP) gene and its two transcripts generated by alternative splicing. SIP induced by stress and promotes cell death. J. Biol. Chem. 276(47) 44185-44192.

Tomasini, R., Samir, A. A., Pebusque, M. J., Calvo, E. L., Totaro, S., Dagorn, J. C., Dusetti, N. J, lovanna, J. L., 2002. $\mathrm{P}^{53}$-dependent expression of the stress-induced protein (SIP). Eur. J. Cell Biol. 81(5) 294-301.

Ulrich, P., Cerami, A., 2001. Protein glycation, diabetes, and aging. Recent Prog. Horm. Res. $561-21$.

Valen, G., 2003. Cellular signalling mechanisms in adaptation to ischemia-induced myocardial damage. Ann. Med. 35(5) 300-307.

Vellaichamy, E., Khurana, M. L., Fink, J., Pandey, K. N., 2005. Involvement of the NF-kappa $\mathrm{B} /$ matrix metalloproteinase pathway in cardiac fibrosis of mice lacking guanylyl cyclase/natriuretic peptide receptor A. J. Biol. Chem. 280(19) 19230-19242.

Verzijl, N., DeGroot, J., Oldehinkel, E., Bank, R. A., Thorpe, S. R., Baynes, J. W., Bayliss, M. T., Bijlsma, J. W., Lafeber, F. P., Tekoppele, J. M., 2000. Age-related accumulation of 
Maillard reaction products in human articular cartilage collagen. Biochem. J. 350 Pt 2 $381-387$.

Vlassara, H., 2001. The AGE-receptor in the pathogenesis of diabetic complications.

Diabetes Metab. Res. Rev. 17(6) 436-443.

Vlassara, H., Cai, W., Crandall, J., Goldberg, T., Oberstein, R., Dardaine, V., Peppa, M., Rayfield, E. J., 2002. Inflammatory mediators are induced by dietary glycotoxins, a major risk factor for diabetic angiopathy. Proc. Natl. Acad. Sci. U. S. A. 99(24) 1559615601.

Webster, J., Wilke, M., Stahl, P., Kientsch-Engel, R., Munch, G., 2005. Maillard reaction products in food as pro-inflammatory and pro-arteriosclerotic factors of degenerative diseases. Z. Gerontol. Geriatr. 38(5) 347-353.

Weiner, L. M., Hu, H., Swartz, H. M., 1991. EPR method for the measurement of cellular sulfhydryl groups. FEBS Lett. 290(1-2) 243-246.

Winyard, P. G., Moody, C. J., Jacob C., 2005. Oxidative activation of antioxidant defence. Trends Biochem. Sci. 30(8) 453-61.

Wolffenbuttel, B. H., Boulanger, C. M., Crijns, F. R., Huijberts, M. S., Poitevin, P., Swennen, G. N., Vasan, S., Egan, J. J., Ulrich, P., Cerami, A., Levy, B. I., 1998. Breakers of advanced glycation end products restore large artery properties in experimental diabetes. Proc. Natl. Acad. Sci. U. S. A. 95(8) 4630-4634.

Zill, H., Bek, S., Hofmann, T., Huber, J., Frank, O., Lindenmeier, M., Weigle, B., Erbersdobler, H. F., Scheidler, S., Busch, A. E., Faist, V., 2003. RAGE-mediated MAPK activation by food-derived AGE and non-AGE products. Biochem. Biophys. Res. Commun. 300(2) 311-315.

Zill, H., Gunther, R., Erbersdobler, H. F., Folsch, U. R., Faist, V., 2001. RAGE expression and AGE-induced MAP kinase activation in Caco-2 cells. Biochem. Biophys. Res. Commun. 288(5) 1108-1111. 


\begin{tabular}{|c|c|c|c|c|}
\hline Transcript & Primer sequence & $\begin{array}{l}\text { Product } \\
\text { length }\end{array}$ & $\begin{array}{l}\text { Annealing } \\
\text { temperature }\end{array}$ & $\begin{array}{l}\text { Accession } \\
\text { number }\end{array}$ \\
\hline $18 \mathrm{~S}$ & $\begin{array}{l}\text { se: GTTGGTGGAGCCGATTTGTCTGG } \\
\text { as: AGGGCAGGGACTTAATCAACGC }\end{array}$ & 346 & & X00686 \\
\hline Catalase & $\begin{array}{l}\text { se: CAGGTTTCTTTCTTGTTCAG } \\
\text { as: GTAGGGACAGTTCACAGGTAT }\end{array}$ & & 61 & NM_009804 \\
\hline Cox7c & $\begin{array}{l}\text { se: AGAACTTCCAGCAGCGACT } \\
\text { as: TAAAGAAAGGTGCGGCAAAC }\end{array}$ & 181 & 52 & XM_001477263 \\
\hline Cp & $\begin{array}{l}\text { se: TTCAGCCAATGGGAGTAAGTTT } \\
\text { as: TGCATGTGTGAACATCCTGATA }\end{array}$ & 374 & 55 & NM_007752 \\
\hline $\mathrm{Cu} / \mathrm{Zn}-$ & se: TGAAGAGAGGCATGTTGGAGAC & 172 & 61 & NM_011434 \\
\hline SOD & as: TTCTTCATTTCCACCTTTGCCC & & & \\
\hline Ec - SOD & $\begin{array}{l}\text { se: AGCTGGCTTTGCTTCTCTTG } \\
\text { as: GGTCAAGCCTGTCTGCTAGG }\end{array}$ & 326 & 61 & NM_011435 \\
\hline Gp91 ${ }^{\text {phox }}$ & se: TCGAAGACAACTGGACAGGAA & 379 & 55 & NM_007807 \\
\hline (Nox2) & as: GAAGAAGATCACAAAGAGATG & & & \\
\hline GSTm1 & $\begin{array}{l}\text { se: GAGATACACCATGGGTGACG } \\
\text { as: AGGCACTTGGGCTCAAAC }\end{array}$ & 432 & 52 & NM_010358.5 \\
\hline Mn - SOD & $\begin{array}{l}\text { se: CCGAGGAGAAGTACCACGAG } \\
\text { as: GAAGGTAGTAAGCGTGCTCC }\end{array}$ & 281 & 55 & NM_013671 \\
\hline Mt1 & $\begin{array}{l}\text { se: GGTCCTCTAAGCGTCACCAC } \\
\text { as: AGGAGCAGCAGCTCTTCTTG }\end{array}$ & 191 & 55 & NM013602 \\
\hline Mt2 & $\begin{array}{l}\text { se: CCGATCTCTCGTCGATCTTC } \\
\text { as: ACTTGTCGGAAGCCTCTTTG }\end{array}$ & 209 & 55 & NM008630 \\
\hline Nox4 & se: AACCTCTTCTTTGTCTTCTAC & 296 & 58 & NM_015760 \\
\hline
\end{tabular}


as: AGGCACAAAGGTCCAGAAAT

$\begin{array}{lllll}\text { Sip } & \text { se: CTGCATCTTTGGAATGCTT } & 421 & 55 & \text { NM021897 } \\ \text { Vnn1 } & \text { as: CGACGGAGACCATTTCTGTT } & & & \\ & \text { se: AGGGTAAACTGGTTGCGAGATA } & 391 & 58 & \text { NM_011704 } \\ \text { Vnn3 } & \text { as: AGTTTTCCTTCTTGGGTCTTCC } & & \\ & \text { se: TCACCAAGCTTACAGGAAGTGC } & 313 & 58 & \text { NM011979 } \\ \text { XDH } & \text { as: GCAAGTTGACTCCCACTTAGCA } & & \\ & \text { se: CAAGGCCTTCACACCAAGAT } & 394 & 55 & \text { NM_011723 } \\ & \text { as: GGTCCCCTGTTAAGCAGTCA } & & \end{array}$

Table 1: Primer sequences and annealing conditions used in RT-PCR analysis as described in "Materials and Methods" 


\begin{tabular}{|c|c|c|c|c|}
\hline \multirow[b]{2}{*}{ Gene } & & \multicolumn{3}{|c|}{ Inhibition of BCE induced expression (\%) } \\
\hline & $\begin{array}{l}\text { BCE-induced } \\
\text { expression } \\
\text { (fold of control) }\end{array}$ & $\begin{array}{c}\text { NAC } \\
\% \\
\text { inhibition }\end{array}$ & $\begin{array}{c}\text { UO126 } \\
\% \\
\text { inhibition }\end{array}$ & $\begin{array}{c}\text { SB203580 } \\
\% \\
\text { inhibition }\end{array}$ \\
\hline Vnn3 & $15.01 \pm 1.56$ & $60 *$ & $38 *$ & $47 *$ \\
\hline Mt2 & $1.88 \pm 0.45$ & $85 *$ & $100 *$ & 0 \\
\hline Vnn1 & $2.53 \pm 0.53$ & $75 *$ & activation & 55 \\
\hline SOD3 & $1.43 \pm 0.11$ & 30 & 20 & 46 \\
\hline MnSOD & $3.99 \pm 0.37$ & 0 & $57 *$ & $34(\ddagger)$ \\
\hline $\mathrm{Cp}$ & $1.44 \pm 0.36$ & 26 & $38 *$ & 47 \\
\hline Gp 91 phox & $3.63 \pm 0.43$ & 43 & $31(\dagger)$ & 33 \\
\hline $\mathrm{XDH}$ & $2.13 \pm 0.29$ & 26 & $\begin{array}{c}\text { activation } \\
(\S)\end{array}$ & activation \\
\hline
\end{tabular}

Table 2: Effect of signalling inhibitors on BCE-induced gene activation. Gene expression in mouse cardiac fibroblasts upon exposure to bread crust extract with and without preincubation with specific signalling inhibitors was determined by RT-PCR (see "Materials and Methods" for details). The BCE effect is expressed as "fold-induction" in comparison to untreated controls. Inhibitor effects are expressed as percentage of reduction of bread crust induced increase in mRNA accumulation.

*: significant with $\mathrm{p}<0.05$;

$(\dagger) \mathrm{p}=0.07 ;(\ddagger) \mathrm{p}=0.09 ;(\S)$ : Activation of expression in controls without BCE 
ACCEPTED MANUSCRIPT
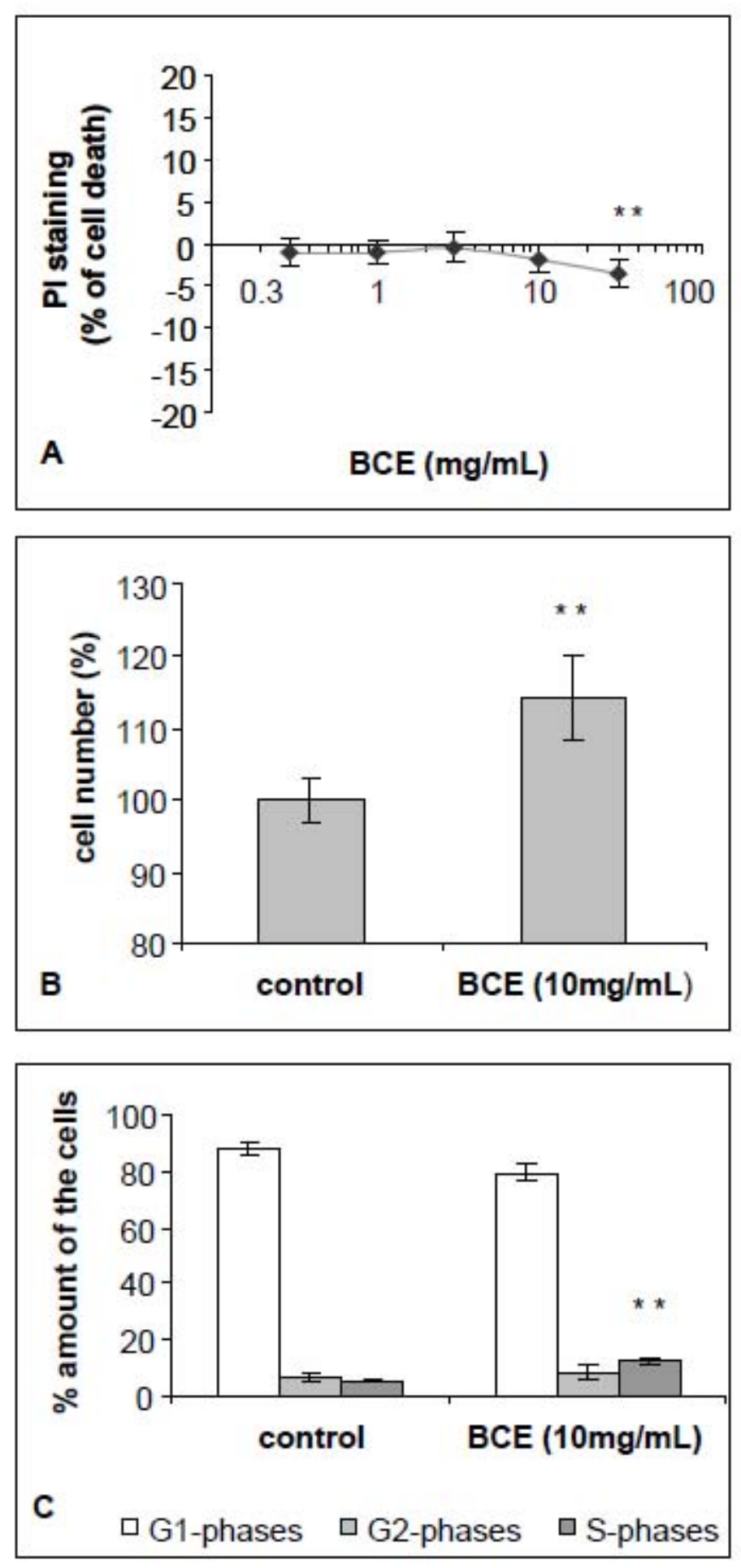

Fig. 1 

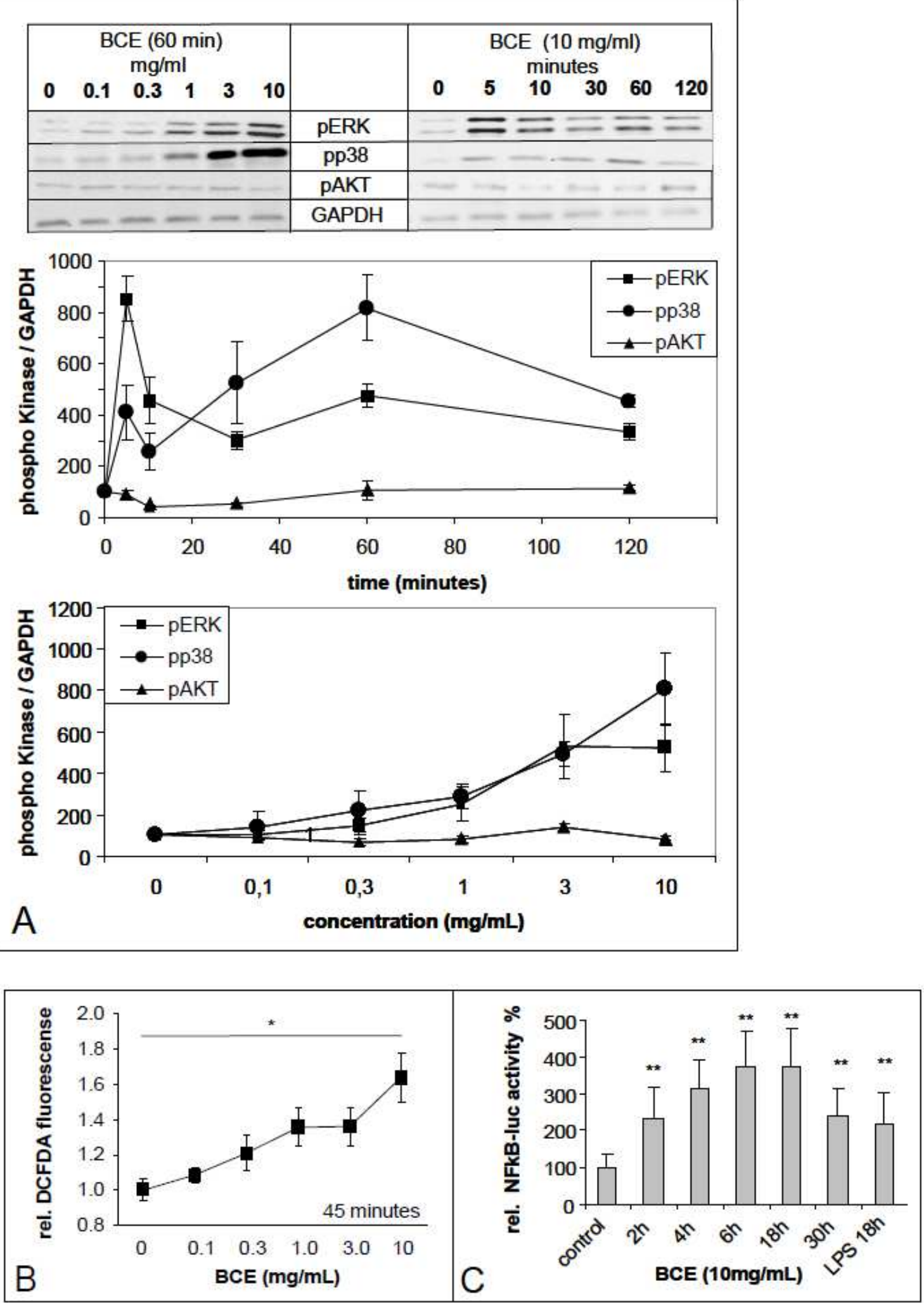

Fig. 2 


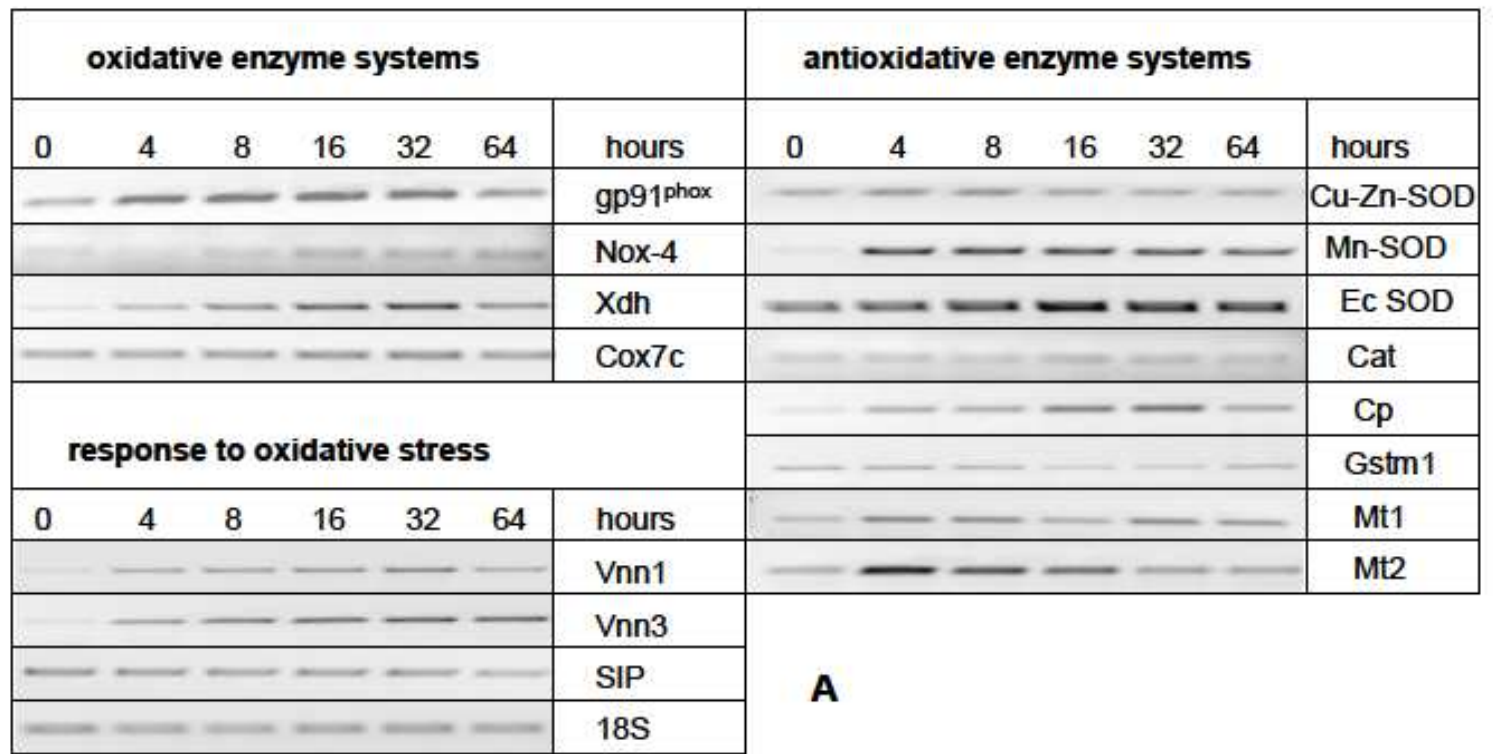
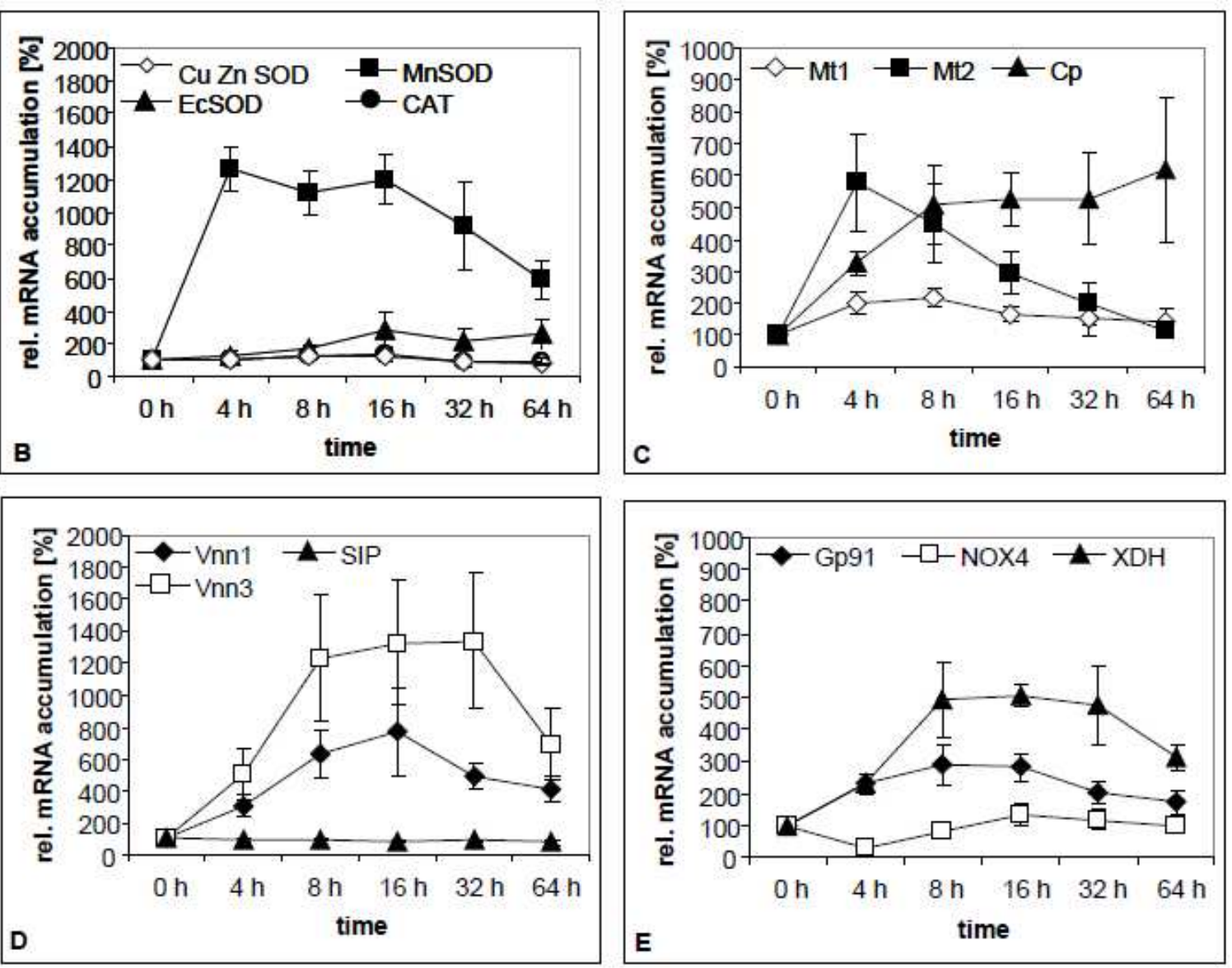

Fig. 3 

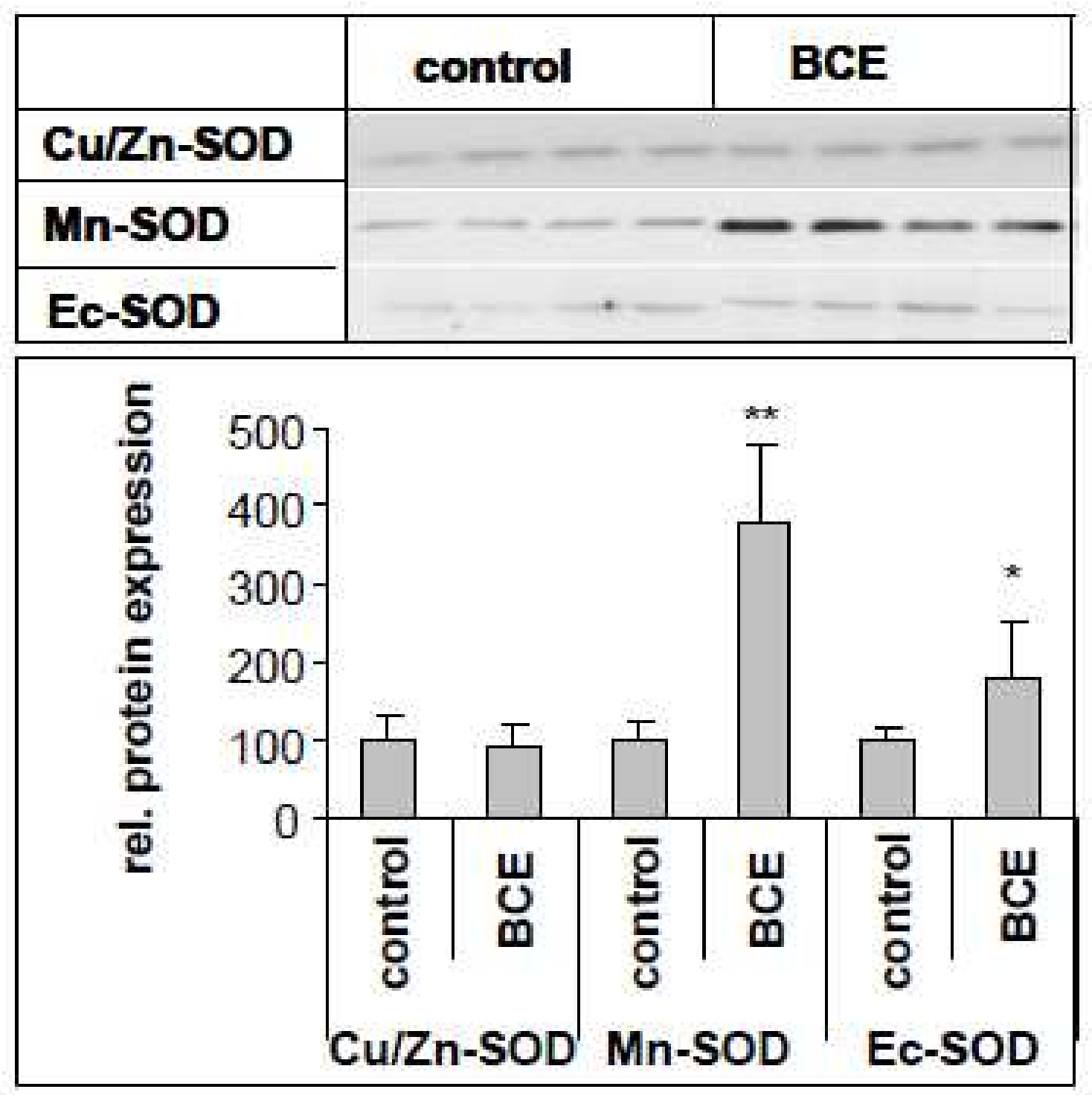

Fig. 4 

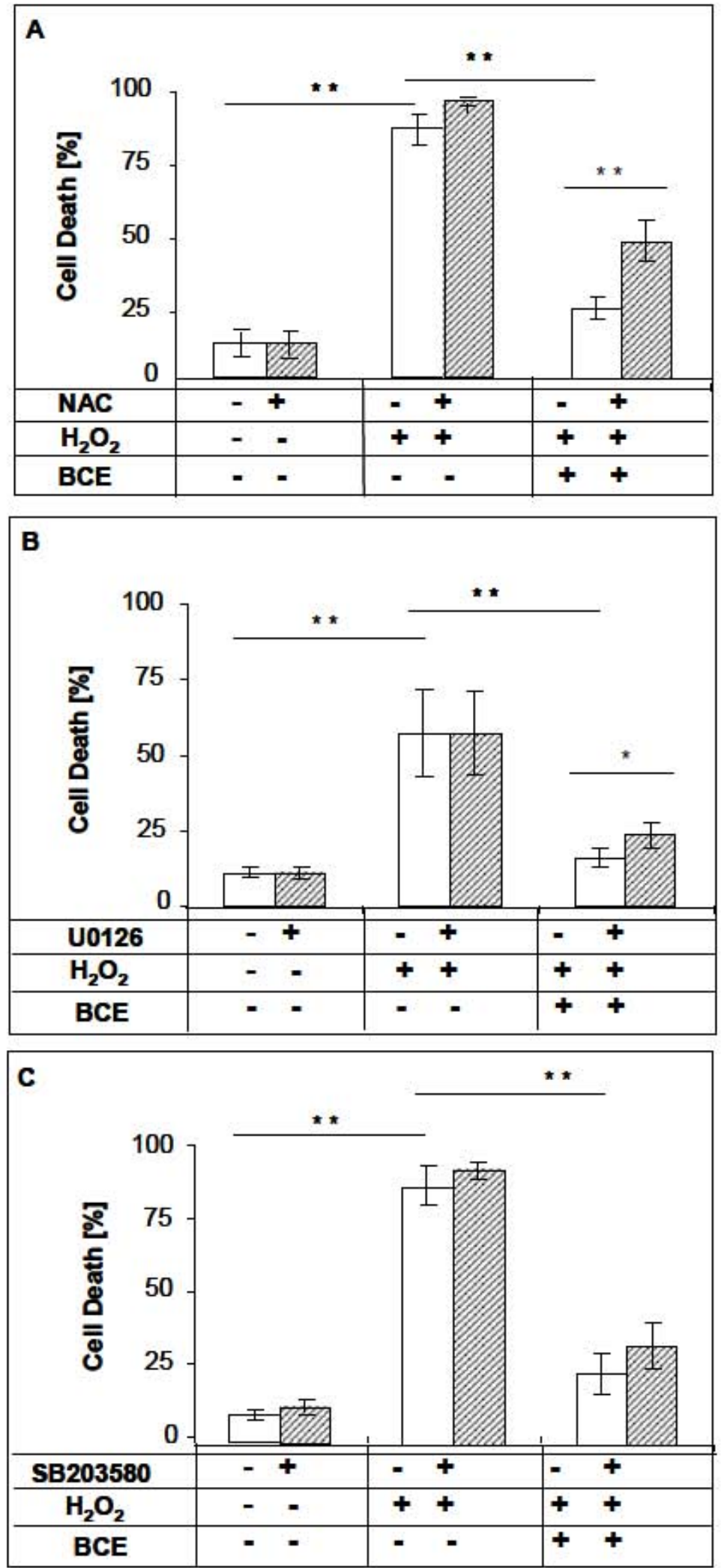

Fig. 5 


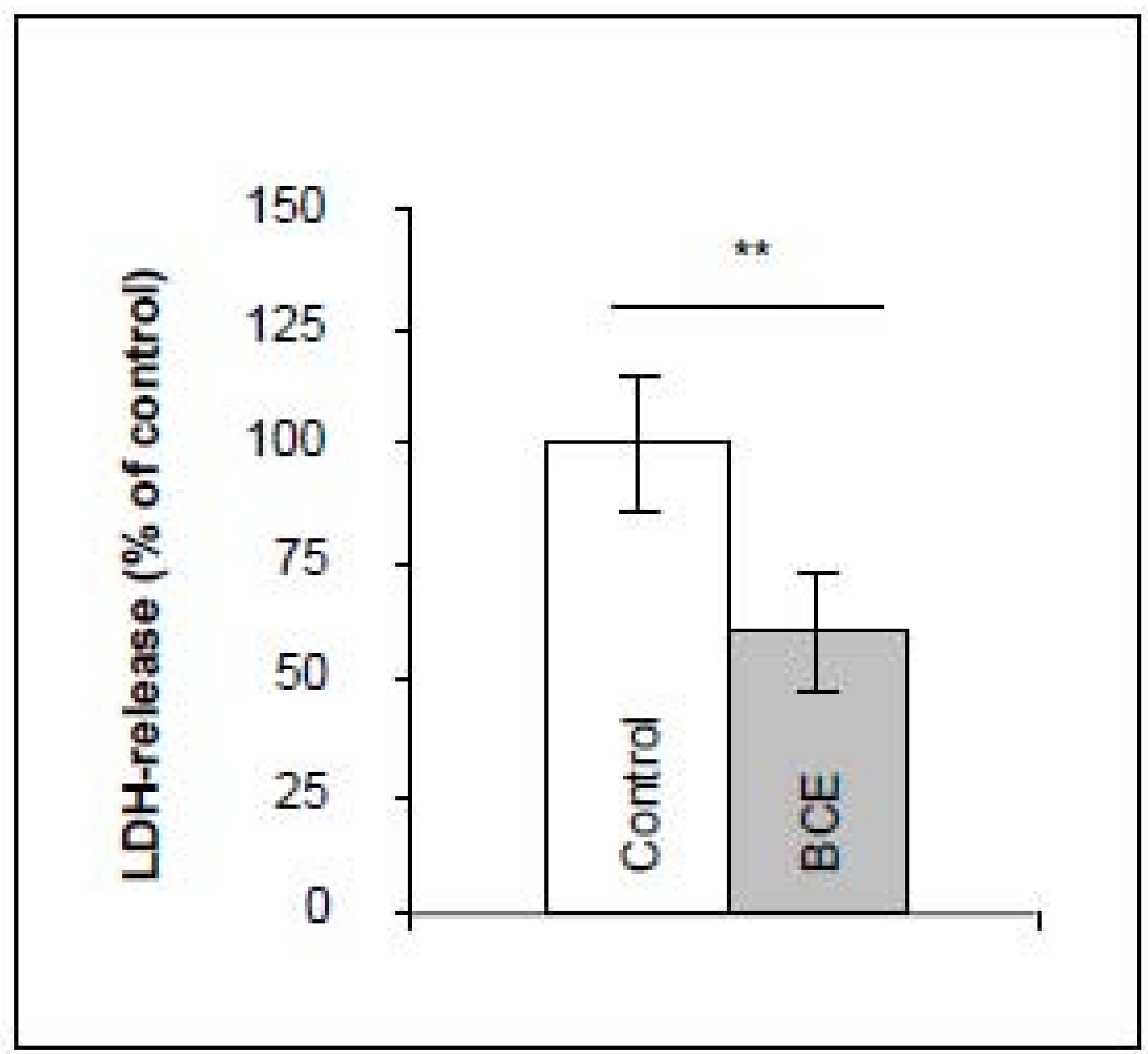

Fig. 6 


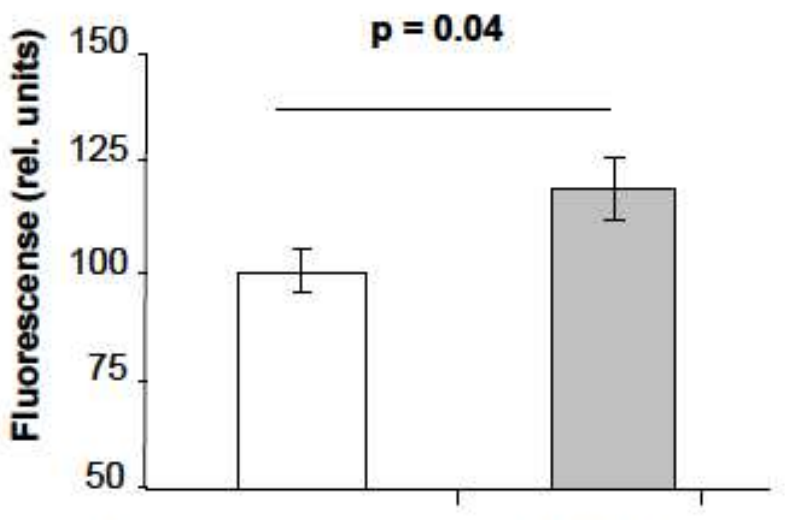

A control

혼

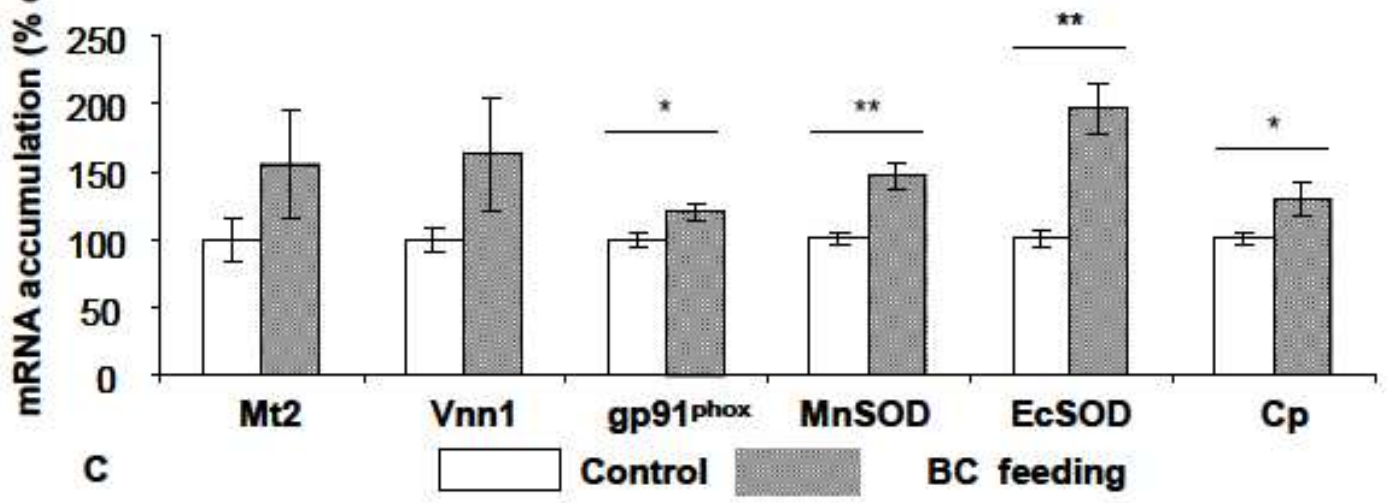

D

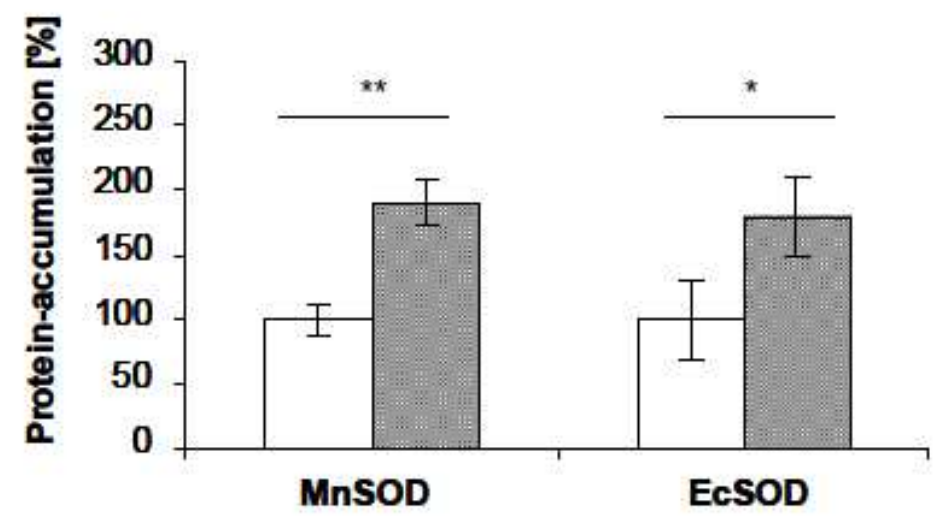

E

Fig. 7 